\title{
Sistem Informasi Lelang Pengadaan Barang Online Menggunakan Metode Analytical Hierarchy Process (AHP) Pada PT Asia Pacific Fibers
}

\author{
Apit Priatna ${ }^{1 *}$, Arif Maulana Yusuf ${ }^{2 * *}$, Yunus Gloria Liem ${ }^{3 *}$ \\ 1,3* Sistem Infromasi, STMIK Rosma \\ ${ }^{2 * *}$ Komputerisasi Akuntansi, STMIK Rosma \\ apit.priatna@dosen.rosma.ac.id ${ }^{1}$, arif@ rosma.ac.id ${ }^{2}$, yunus@mhs.rosma.ac.id ${ }^{3}$
}

\begin{tabular}{l} 
Article Info \\
\hline Article history: \\
Received 11-11-2020 \\
Revised 23-06-2021 \\
Accepted 14-07-2021 \\
\hline
\end{tabular}

Keyword:

AHP (Analytic Hierarchy

Process), Lelang

\begin{abstract}
The online auction system in the procurement of goods can make it easier to supervise and avoid fraud in the auction process so as to create transparency and accountability of data in the auction process to auction participants, where with a company system and auction participants can be connected quickly to get information. The method used for data processing using AHP (Analytic Hierarchy Process). The stages in the AHP method begin with the process of defining the problem, creating a hierarchical structure that begins with a general purpose, followed by criteria and choice alternatives, Creating a paired comparison matrix, normalizing data, calculating the eigenvector value and testing its consistency, calculating the eigenvector of each Pairwise comparison matrix, Test the consistency of the hierarchy. If it does not meet the CR $<0.100$ then the assessment must be repeated. Calculations using the AHP (Analytic Hierarchy Process) method are faster than manual calculations so that they can be more efficient and the level of data accuracy is close to perfect. So that it has the convenience of providing information to auction participants about the auction package to be carried out, avoiding fraud in the auction process.
\end{abstract}

This is an open access article under the CC-BY-SA license

\section{Pendahuluan}

Saat ini teknologi semakin berkembang dari zaman ke zaman dan kian mengalami kemajuan yang sangat pesat. Teknologi yang semakin berkembang mempunyai tujuan untuk mempermudah serta membantu setiap pekerjaan manusia. Hampir setiap hari kegiatan dipengaruhi oleh teknologi, seperti dari pendidikan, kehidupan sehari-hari hingga transaksi jual beli[1].

Pada zaman yang serba menggunakan teknologi saat ini setiap perusahaan membutuhkan teknologi untuk membantu mempercepat pekerjaan yang masih dilakukan secara manual, contohnya seperti pengadaan barang[2]-[3]. Pengadaan merupakan proses kegiatan untuk pemenuhan atau penyediaan kebutuhan dan pasokan barang serta jasa di bawah kontrak atau pembelian langsung untuk memenuhi kebutuhan bisnis. Barang juga didefinisikan sebagai suatu produk fisik yang dapat diberikan kepada seorang pembeli dan melibatkan perpindahan kepemilikan dari penjual ke pelanggan[4]-[5].

Salah satu perusahaan yang sedang berusaha memanfaatkan teknologi informasi yaitu PT Asia Pacific Fibers didalam setiap kegiatan oprasionalnya. PT Asia Pacific Fibers didirikan pada tanggal 15 Febuari 1984 dan memulai kegiatan usaha komersilnya pada tahun 1986, kegiatannya meliputi industri kimia dan serat sintetis, pertenunan dan perajutan adapun beberapa produk yang dihasilkan PT Asia Pacific Fibers meliputi Purified Terephthalic Acid (PTA), polyester chips, staple fiber, filament yarn dan performance fabrics. Kebutuhan barang pada PT Asia Pacific Fibers kian meningkat dan mencari informasi sangat sulit, sehingga hal ini yang menjadi dasar penggadaan barang terlambat dalam memberikan informasi yang cepat dan akurat. Oleh sebab itu, dibutuhkannya suatu sistem dimana perusahaan dan supplier dapat terkoneksi secara cepat untuk mendapatkan informasi. 
Informasi tersebut dapat berupa pelelangan pengadaan barang.

Pelelangan pengadaan barang biasanya dilakukan dengan mengajukan suatu permintaan yang diberi standar, kemudian peserta lelang dapat mengajukan diri bersaing dengan peserta lain dan menawarkan diri sebagai pemasok, sehingga peserta lelang yang menawarkan diri sesuai dengan kriteria-kriteria yang telah ditentukan maka akan memenangkan lelang tersebut dan mendapatkan pekerjaan dari lelang tersebut[6]. Selanjutnya PT. Asia Pacific Fibers dapat bergerak cepat mengambil keputusan, memilih supplier secara objektif berdasarkan multi kriteria yang ditetapkan. Salah satu metode yang dapat membantu dalam membuat keputusan yaitu metode Analitycal Hierarchy Process (AHP). Metode AHP adalah metode pengambilan keputusan yang multi kriteria[7], adapun kriteria-kriteria yang digunakan dalam penentuan pemenang lelang yaitu kualitas, kecepatan pengiriman barang, harga barang dan status supplier[6].

Oleh karena itu dalam penelitian ini, dirancang sebuah sistem infomasi lelang secara online yang memiliki kemudahan dalam memberikan informasi kepada para peserta lelang tentang paket pelelangan yang akan dilaksanakan, menghindari terjadinya kecurangan pada proses pelelangan dengan menggunakan metode Analytical Hierarchy Process (AHP).

\section{TINJAUAN PUSTAKA}

\section{Sistem Informasi}

Sistem Informasi adalah suatu sistem didalam suatu organisasi yang mempertemukan kebutuhan pengelolaan transaksi harian, mendukung operasi, bersifat manajerial dan kegiatan strategi dari suatu organisasi dan menyediakan pihak luar tertentu dengan laporan-laporan yang diperlukan[8].

Sistem informasi sebagai seperangkat element yang saling terkait untuk di-input, diproses, disimpan serta disebarkan guna mendapatkan feedback dalam memenuhi tujuan tertentu[9].

\section{Teknologi Informasi}

Lucas menyatakan bahwa teknologi informasi adalah segala bentuk teknologi yang diterapkan untuk memproses dan mengirimkan informasi dalam bentuk elektronis, mikro komputer, komputer mainframe, pembaca barcode, perangkat lunak lembar kerja (Spreadsheet) dan peralatan komunikasi serta jaringan merupakan contoh teknlogi informasi[10].

Martin mendefinisikan teknologi informasi tidak hanya terbatas pada teknlogi komputer (perangkat keras dan perangkat lunak) yang digunakan untuk memproses dan menyimpan informasi melainkan juga mencakup teknologi komunikasi untuk mengirimkan informasi[11].

\section{Analitycal Hierarchy Process (AHP)}

Analitycal Hierarchy Process (AHP) adalah metode untuk memecahkan suatu situasi yang komplek tidak terstruktur kedalam beberapa komponen dalam susunan yang hirarki, dengan memberi nilai subjektif tentang pentingnya setiap variable secara relatif dan menetapkan variable mana yang memiliki prioritas paling tinggi guna mempengaruhi hasil pada situasi tersebut[7].

\section{Lelang}

Dalam peraturan Menteri Keuangan, yang dimaksud dengan Lelang adalah penjualan barang yang terbuka untuk umum dengan penawaran harga secara tertulis dan/atau lisan yang semakin meningkat atau menurun untuk mencapai harga tertinggi yang didahului dengan pengumuman lelang.[12]

\section{Model Pengembangan Sistem Prototype}

Prototyping perangkat lunak adalah salah satu metode siklus hidup sistem yang didasarkan pada konsep model bekerja (working model). Tujuannya adalah mengembangkan model menjadi sistem final. Artinya sistem akan dikembangkan lebih cepat dari pada metode tradisional dan biayanya menjadi lebih rendah[13].

\section{Blackbox Testing}

Blackbox Testing adalah menguji perangkat lunak dari segi spesifikasi fungsional tanpa menguji desain dan kode program. Pengujian ini dimaksudkan untuk mengetahui apakah fungsi-fungsi, masukan dan keluaran dari perangkat lunak sesuai dengan spesifikasi yang dibutuhkan. Berfokus pada spesifikasi fungsional dari perangkat lunak, tester dapat mendefinisikan kumpulan kondisi input dan melakukan pengetesan pada spesifikasi fungsional program.[14]

Blackbox Testing bukanlah solusi alternatif dari Whitebox Testing tapi lebih merupakan perlengkapan untuk menguji hal-hal yang tidak dicakup oleh Whitebox Testing[14]. Blackbox Testing cenderung untuk menemukan hal-hal seperti berikut:

1. Fungsi yang tidak benar atau tidak ada

2. Kesalahan antarmuka (interface errors)

3. Kesalahan pada struktur data dan akses basis data

4. Kesalahan performansi (perfomance errors)

5. Kesalahan inisialisasi dan terminasi

\section{METODE PENELITIAN}

Merupakan teknik atau cara yang dilakukan oleh peneliti untuk mengumpulkan data. Pengumpulan data dilakukan untuk memperoleh informasi yang dibutuhkan dalam rangka mencapai tujuan penelitian, dimana dalam penelitian ini menggunakan tiga metode yaitu :

\section{Metode Pengumpulan Data}

1. Wawancara

Wawancara atau interview adalah tehnik pengumpulan data informasi secara lengkap maka penulis melakukan suatu metode tanya jawab tentang semua kegiatan yang dimana data tersebut didapat dari pihak yang dijadikan informan penelitian. Tehnik wawancara dilakukan dengan mempersiapkan terlebih dahulu pertanyaanpertanyaan yang akan ditanyakan kepada target wawancara[15].

2. Observasi

Observasi adalah teknik pengumpulan data bagaimana cara mendapatkan data informasi dengan mengadakan pengamatan langsung ke objek penelitian[16]. Dalam penelitian ini penulis mengamati kegiatan dalam kantor 
PT Asia Pacific Fibers Tbk bagaimana proses lelang pengadaan barang yang sudah berjalan dari gudang, bagian pembelian, sistem, supplier hingga bagaimana proses pembelian tunai dari meminta barang sampai penerimaan barang. Berikut adalah hasil data observasi di PT Tridana Asia Mandiri setiap bulannya memiliki 30 permintaan dari gudang barang.

\section{Metode Pengembangan Sistem}

Metode pengembangan sistem yang digunakan adalah metode prototyping dapat dikatakan sebagai pengembangan yang cepat dan pengujian terhadap model kerja (prototipe)[9].

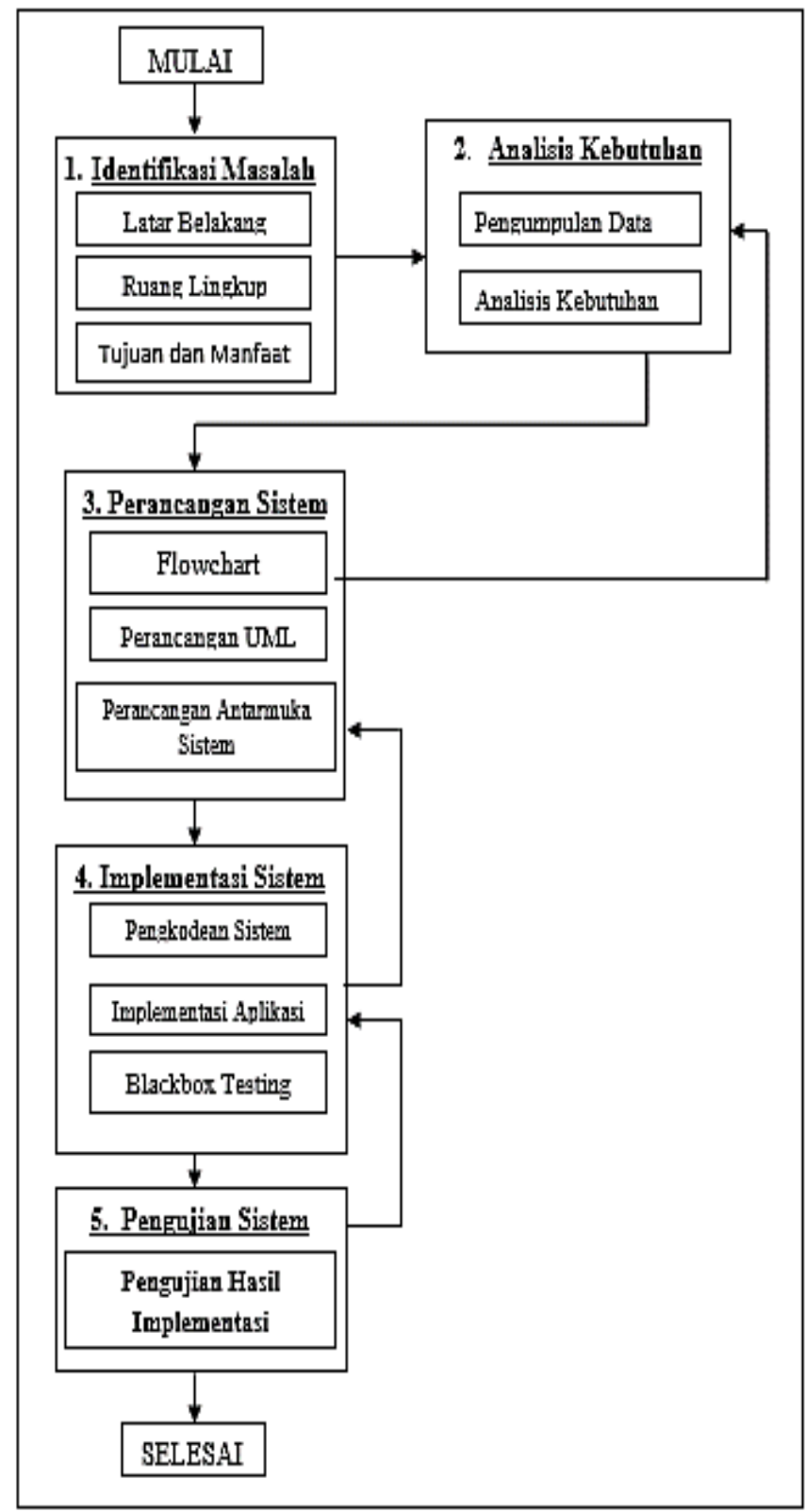

Gambar 1. Alur Prototipe

\section{Metode Pengambilan Keputusan}

1. Analitycal Hierarchy Process $(A H P)$

Analitycal Hierarchy Process (AHP) adalah metode untuk memecahkan suatu situasi yang komplek tidak terstruktur kedalam beberapa komponen dalam susunan yang hirarki, dengan memberi nilai subjektif tentang pentingnya setiap variable secara relatif dan menetapkan variable mana yang memiliki prioritas paling tinggi guna mempengaruhi hasil pada situasi tersebut[7].

AHP sering digunakan sebagai metode pemecahan masalah dibanding dengan metode yang lain karena alasan-alasan sebagai berikut[17] :

a. Struktur yang berhirarki, sebagai konsekuensi dari kriteria yang dipilih, sampai pada subkriteria yang paling dalam

b. Memperhitungkan validitas sampai dengan batas tolerensi berbagai kriteria dan alternatif yang dipilih oleh pengambilan keputusan

c. Memperhitungkan daya tahan output analisis sensitivitas pengambilan keputusan

2. Perhitungan Analitycal Hierarchy Process (AHP)

Kriteria yang di tawarkan oleh sistem, sukses 3 point, pending 2 point, fail 1 point.

TABEL I

CONTOH DATA HISTORY SUPPLIER

\begin{tabular}{|l|c|c|c|c|}
\hline Supplier & Join & Pending & Fail & Succes \\
\hline Bryant & 10 & 2 & 3 & 5 \\
\hline Sonic & 10 & 3 & 2 & 5 \\
\hline Alex & 10 & 1 & 4 & 5 \\
\hline
\end{tabular}

Berikut penjelasan kriteria pada tabel data history supplier :

1. Join

Merupakan jumlah dari seluruh lelang yang telah diikuti oleh supplier

2. Pending

Merupakan jumlah lelang, dimenangkan oleh supplier yang sedang dalam transaksi, namun transaksi tersebut belum terselesaikan

3. Fail

Merupakan jumlah lelang yang dimenangkan oleh supplier dan masuk kedalam tahap transaksi, namun transaksi tersebut bermasalah dan gagal

4. Success

Merupakan jumlah lelang yang dimenangkan oleh supplier dan masuk ke dalam tahap transaksi dan transaksi tersebut terselesaikan dengan baik

\section{HASIL DAN PEMBAHASAN}

Flowchart lelang pengadaan barang, mengambarkan proses atau alur dari awal sampai akhir dalam lelalng pengadaan barang. 


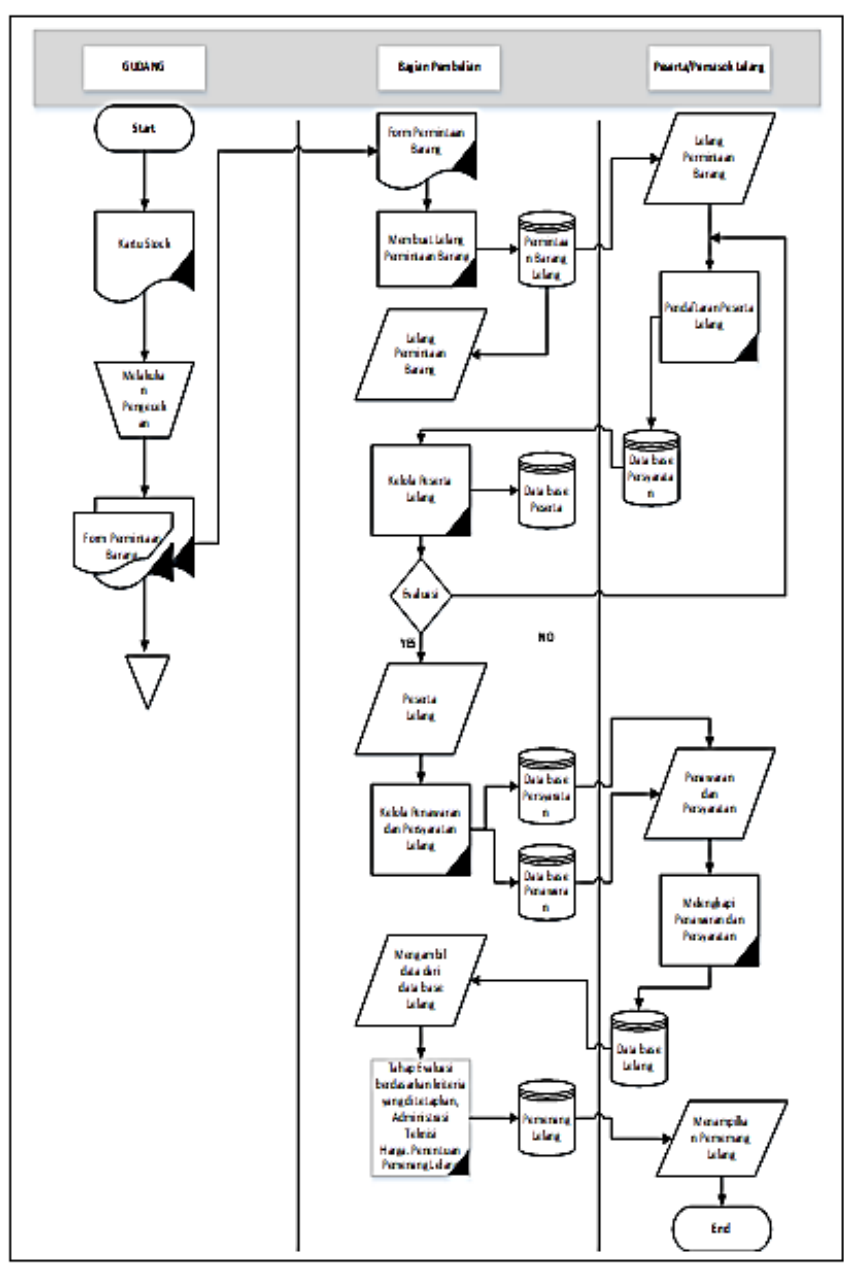

Gambar 2. Flowchart Lelang Pengadaan Barang

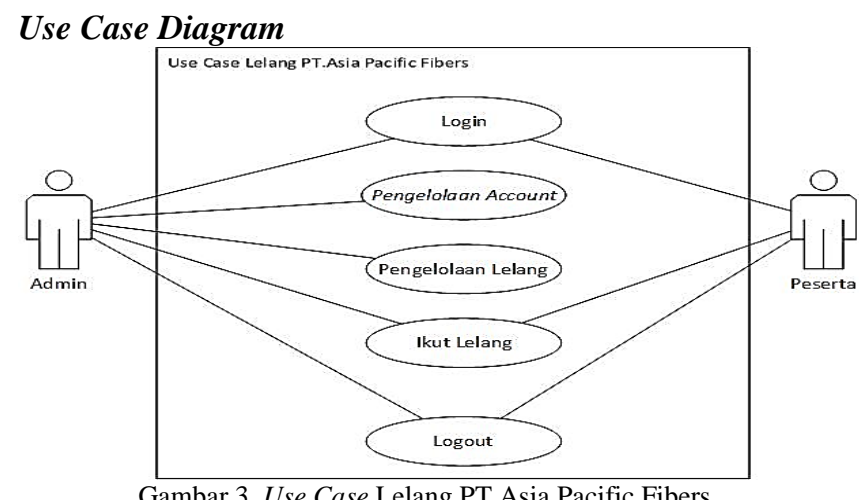

Diagram Use Case yang menjadi rancangan usulan pada PT.Asia Pacific Fibers terdiri dari berbagai pengelolaan layanan seperti pengelolaan account, pengelolaan lelang dan pengelolaan ikut lelang yang harus dilakukan login terlebih dahulu untuk mengakses layanan tersebut.

\section{Activity Diagram}

Diagram aktivitas atau activity diagram menggambarkan workflow (aliran kerja) atau aktivitas dari sebuah sistem atau proses bisnis atau menu yang ada pada perangkat lunak[18].
1. Activity Diagram Registrasi

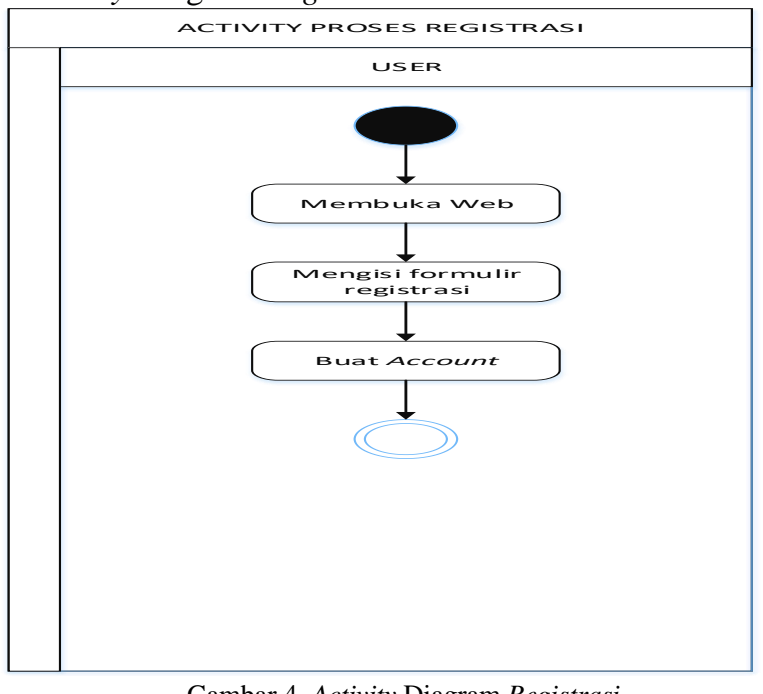

Langka pertama membuka web, kemudian pilih registrasi lalu akan muncul formulir pendaftaran yang harus diisi oleh calon peserta. Selanjutnya klik buat account

2. Activity Diagram Login

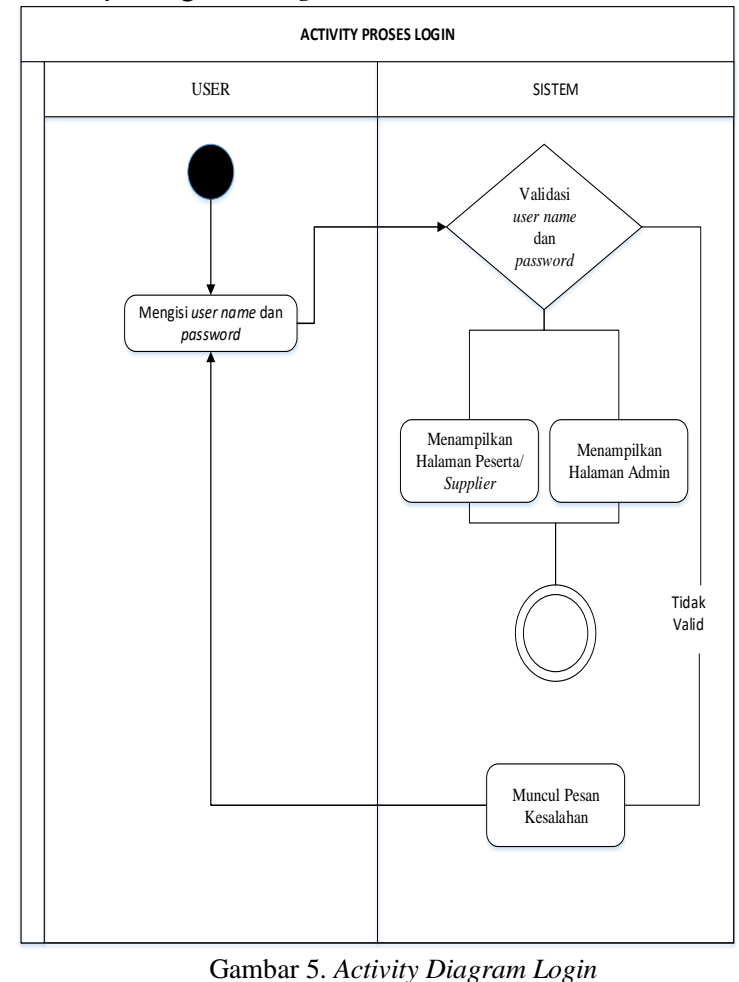

User akan melakukan login, memasukan username dan password. Tahap selanjutnya sistem akan melakukan proses decision apakah harus menampilkan halaman peserta atau admin. Apabila username dan password tidak valid maka akan muncul pesan kesalahan 
3. Activity Diagram Membuat Lelang

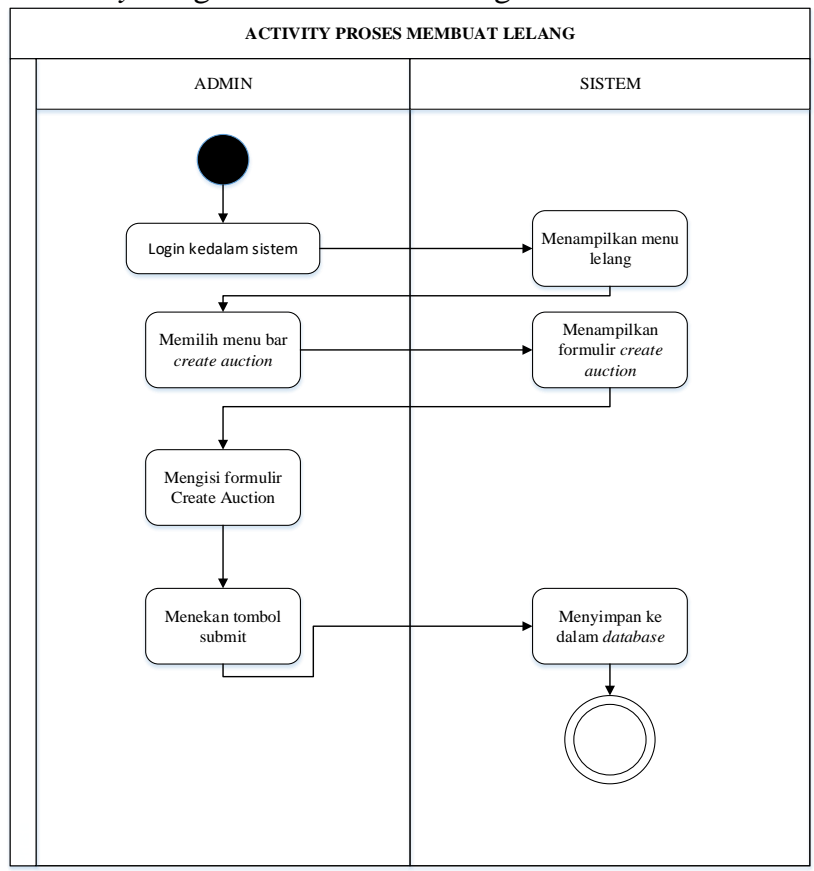

Gambar 6. Activity Diagram Membuat Lelang

Langkah pertama admin login kedalam sistem, kemudian sistem akan menampilkan menu lelang dan selanjutnya admin akan memilih menu bar create auction. Tahap selanjutnya sistem akan menampilkan formulir create auction lalu admin akan mengisi formulir dengan lengkap dan menekan tombol submit, selanjutnya sistem akan menyimpan dalam database

4. Activity Diagram Mengakhiri Lelang

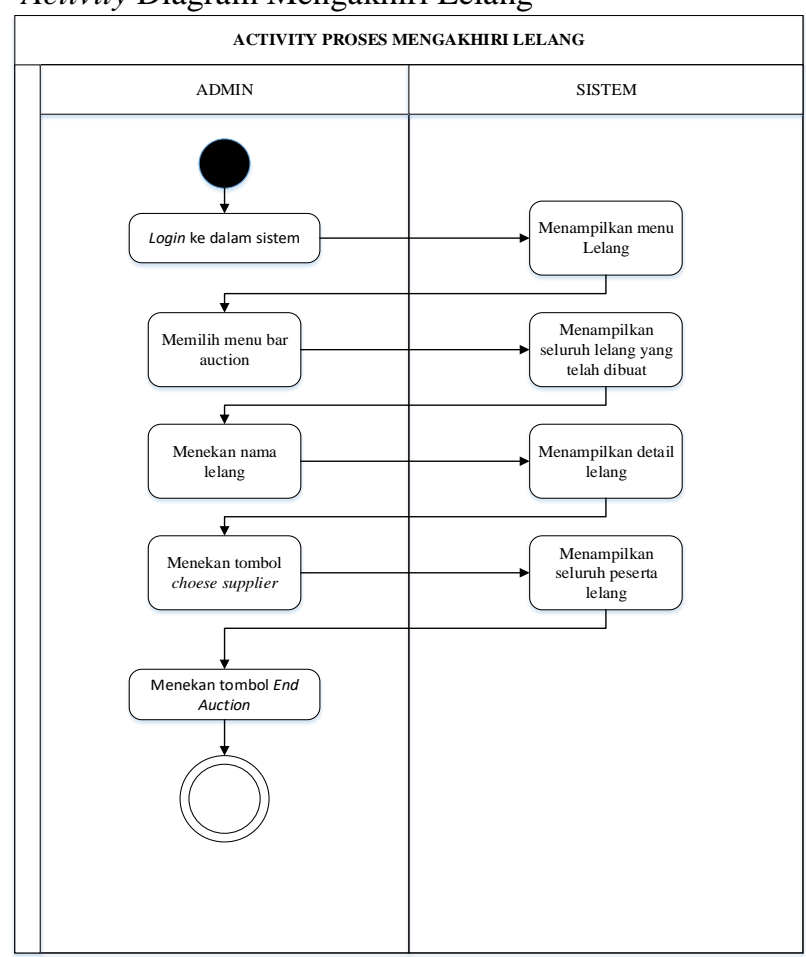

Gambar 7. Activity Diagram Mengakhiri Lelang
Langkah pertama admin akan login ke dalam sistem kemudian sistem akan menampilkan menu lelang, selanjutnya admin akan memilih menu bar auction, lalu sistem akan menampilkan seluurh lelang yang dibuat. Tahap selanjutnya admin akan menekan nama lelang dan sistem akan menampilkan detai lelangnya, kemudian admin akan menekan tombol chose supplier, selanjutnya sistem akan menampilkan seluruh peserta lelang dan kemudian admin akan menekan tombol End Auction.

\section{Class Diagram}

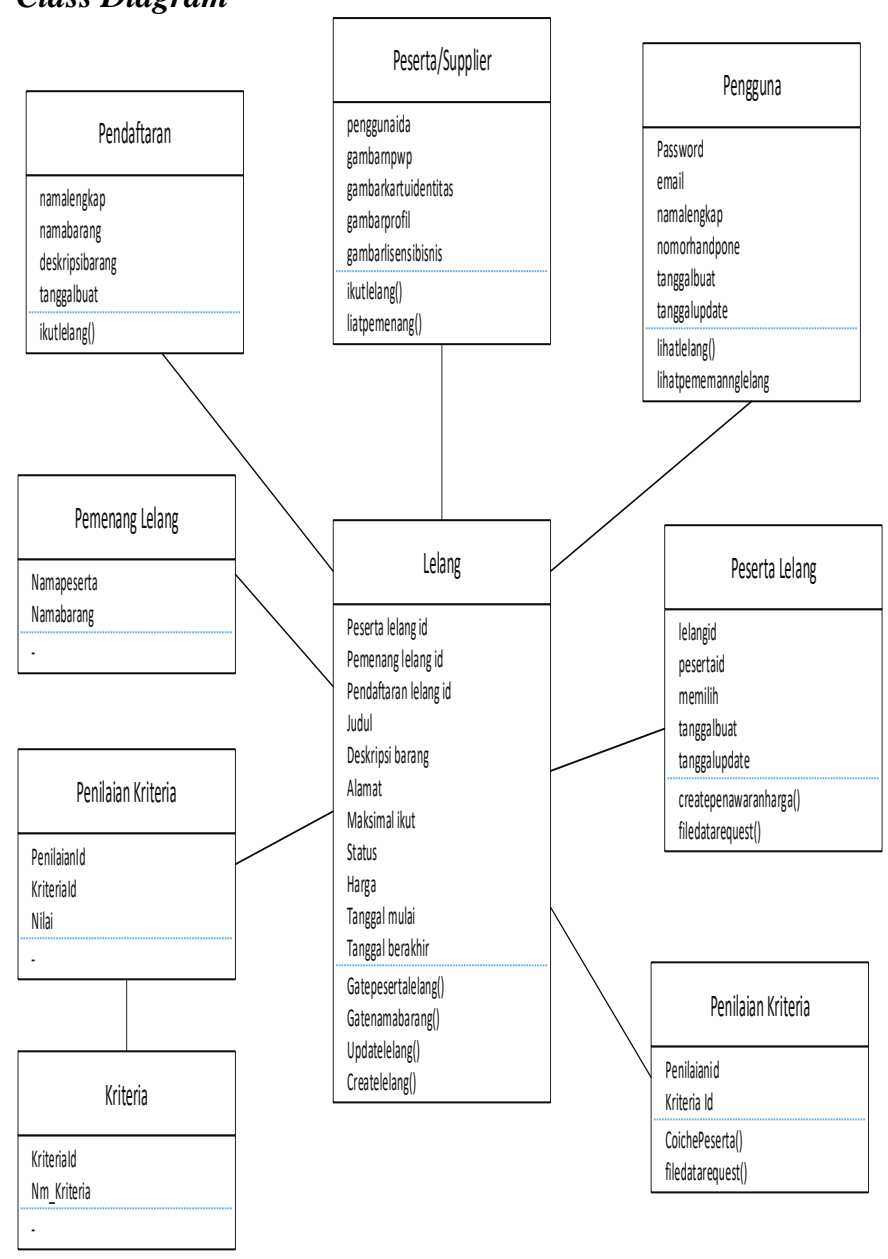

Gambar 8. Class Diagram

Menggambarkan hubungan dan interaksi dari setiap class yang terdapat pada sistem lelang serta method yang dapat dilakukan oleh setiap class nya.

\section{Analytical Hierarchy Process}

Pada penerapan $A H P$ berikut akan dijelaskan secara detail (langkah demi langkah) pada proses penentuan pemenang peserta/supplier:

1. Menyusun Hirarki 


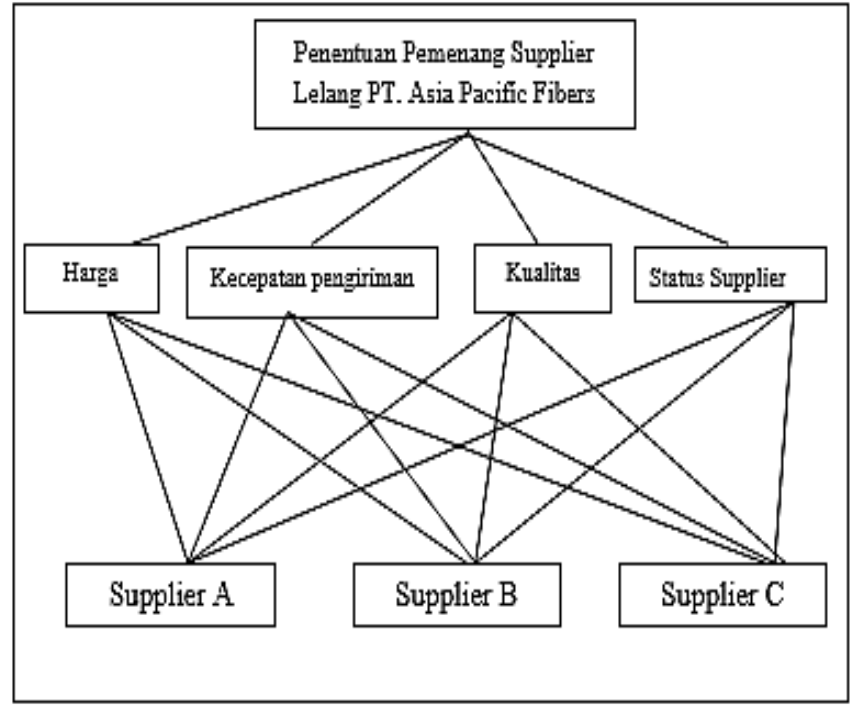

Gambar 9. Hirarki AHP

2. Menetapkan Prioritas

TABEL II

TABLE PRIORITAS

\begin{tabular}{|l|l|l|l|l|}
\hline Kriteria & Harga & $\begin{array}{l}\text { Kecepatan } \\
\text { pengiriman }\end{array}$ & Kualitas & $\begin{array}{l}\text { Status } \\
\text { Supplier }\end{array}$ \\
\hline Harga & 1 & 3 & 3 & 4 \\
\hline $\begin{array}{l}\text { Kecepatan } \\
\text { pengiriman }\end{array}$ & $1 / 3$ & 1 & 3 & 4 \\
\hline Kualitas & $1 / 4$ & $1 / 3$ & 1 & 3 \\
\hline $\begin{array}{l}\text { Status } \\
\text { Supplier }\end{array}$ & $1 / 4$ & $1 / 3$ & $1 / 4$ & 1 \\
\hline Jumlah & 0,833333 & 4,666666 & 7,25 & 12 \\
\hline
\end{tabular}

Tetapkan nilai kepentingan dengan membuat matriks yang akan membandingkan kritera penilaian secara berpasangan. Kemudian jumlahkan tiap kolomnya. Bagi nilai masukkan dengan nilai jumlah kolom yang bersesuaian. Kemudian jumlahkan perbarisnya, lalu bagi jumlah baris dengan banyaknya kriteria.

TABEL III

TABLE PERBANDINGAN

\begin{tabular}{|c|c|c|c|c|c|c|}
\hline $\begin{array}{l}\text { Kriter } \\
\text { ia }\end{array}$ & Harga & $\begin{array}{l}\text { Kecep } \\
\text { atan } \\
\text { Pengiri } \\
\text { man }\end{array}$ & $\begin{array}{l}\text { Kual } \\
\text { itas }\end{array}$ & $\begin{array}{l}\text { Stat } \\
\text { us } \\
\text { Supp } \\
\text { lier }\end{array}$ & $\sum_{\text {Baris }}$ & $\begin{array}{l}\text { Vect } \\
\text { or } \\
\text { prior } \\
\text { itas }\end{array}$ \\
\hline Harga & $\begin{array}{l}(1) / 0,8 \\
33333\end{array}$ & $\begin{array}{l}(3) / \\
4,6666 \\
66 \\
\end{array}$ & $\begin{array}{l}(3) / \\
7,25\end{array}$ & $\begin{array}{l}(4) / 1 \\
2\end{array}$ & $\begin{array}{l}2,589 \\
983\end{array}$ & $\begin{array}{l}0.647 \\
495\end{array}$ \\
\hline $\begin{array}{l}\text { Kecep } \\
\text { atan } \\
\text { Pengir } \\
\text { iman }\end{array}$ & $\begin{array}{l}(1 / 3) / \\
0,83333 \\
3\end{array}$ & $\begin{array}{l}(1) / \\
4,6666 \\
66\end{array}$ & $\begin{array}{l}(3) / \\
7,25\end{array}$ & $\begin{array}{l}2^{(4) / 1} \\
\end{array}$ & $\begin{array}{l}1,361 \\
41\end{array}$ & $\begin{array}{l}0,340 \\
352\end{array}$ \\
\hline $\begin{array}{l}\text { Kualit } \\
\text { as }\end{array}$ & $\begin{array}{l}(1 / 4) / \\
0,83333 \\
3\end{array}$ & $\begin{array}{l}(1 / 3) / \\
4,6666 \\
66\end{array}$ & $\begin{array}{l}(1) / \\
7,25\end{array}$ & $\begin{array}{l}(3) / 1 \\
2\end{array}$ & $\begin{array}{l}0,759 \\
359\end{array}$ & $\begin{array}{l}0,189 \\
839\end{array}$ \\
\hline $\begin{array}{l}\text { Status } \\
\text { suppli } \\
\text { er }\end{array}$ & $\begin{array}{l}(1 / 4) / \\
0,83333 \\
3\end{array}$ & $\begin{array}{l}(1 / 3) / \\
4,6666 \\
66\end{array}$ & $\begin{array}{l}(1 / 4) \\
/ 7,25\end{array}$ & $\begin{array}{l}(1) / 1 \\
2\end{array}$ & $\begin{array}{l}0,489 \\
243\end{array}$ & $\begin{array}{l}0,122 \\
310\end{array}$ \\
\hline
\end{tabular}

3. Konsistensi Logis

Ambil matrik pertama (pembobotan pertama) kalikan dengan vector prioritas yang bersesuaian dengan masukan jumlah perbaris.

TABEL IV

TABLE NORMALISASI

\begin{tabular}{|l|l|l|l|l|l|}
\hline Kriteria & $\begin{array}{l}\text { Harga } \\
(0.6474 \\
95)\end{array}$ & $\begin{array}{l}\text { Kecepat } \\
\text { an } \\
\text { Pengiri } \\
\text { man } \\
(0.3403 \\
52)\end{array}$ & $\begin{array}{l}\text { Kualita } \\
\text { s } \\
(0.1898\end{array}$ & $\begin{array}{l}\text { Status } \\
\text { Supplie } \\
\mathrm{r}\end{array}$ & $\begin{array}{l}\text { Baris- } \\
(0.1223\end{array}$ \\
& & $10)$ & \\
\hline Harga & $(1)$ & $(3)$ & $(3)$ & $(4)$ & 2.7273 \\
& $(0.6474$ & $(0.3403$ & $(0.1898$ & $(0.1223$ & 08 \\
& $95)$ & $52)$ & $39)$ & $10)$ & \\
\hline $\begin{array}{l}\text { Kecepat } \\
\text { an }\end{array}$ & $(1 / 3)$ & $(1)$ & $(3)$ & $(4)$ & 1.6149 \\
Pengiri & $(0.6474$ & $(0.3403$ & $(0.1898$ & $(0.1223$ & 4 \\
man & $95)$ & $52)$ & $39)$ & $10)$ & \\
\hline Kualitas & $(1 / 4)$ & $(1 / 3)$ & $(1)$ & $(3)$ & 0.8320 \\
& $(0.6474$ & $(0.3403$ & $(0.1898$ & $(0.1223$ & 92 \\
& $95)$ & $52)$ & $39)$ & $10)$ & \\
\hline Status & $(1 / 4)$ & $(1 / 3)$ & $(1 / 4)$ & $(1)$ & 0.4450 \\
Supplier & $(0.6474$ & $(0.3403$ & $(0.1898$ & $(0.1223$ & 92 \\
& $95)$ & $52)$ & $39)$ & $10)$ & \\
\hline
\end{tabular}

Bagi jumlah baris ke-2 dengan vector prioritas yang bersesuaian.

TABEL V

HASIL BARIS 2 DAN VECTOR

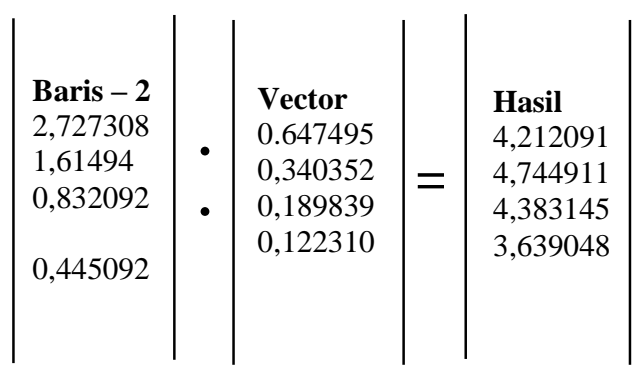

Hitung CI:

$\mathrm{CI}=\underline{4,244798-4}=0,081599$ 4-1

Hitung nilai $\mathrm{CR}$

$\mathrm{CR}=\underline{0,081599}=0,090$ 0,90

Karena nilai CR $<0.100$, maka dinyatakan data layak diuji dengan tidak adanya pengubahan data. 


\section{Implementasi Sistem}

Implementasi sistem adalah tahapan suatu proses di dalam perangkat lunak yang bertujuan untuk menjalankan aplikasi yang telah selesai dirancang dan dibangun agar bisa mengetahui apakah suatu sistem tersebut sudah layak untuk diimplementasikan atau belum[19]-[20].

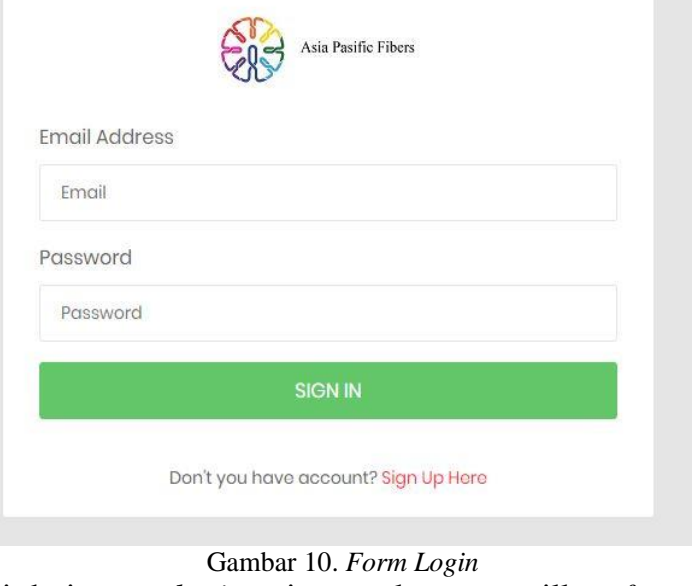

Fungsi dari menu login yaitu untuk menampilkan form login yang terdiri dari label username dan password yang akan digunakan unuk login ke dalam sistem.

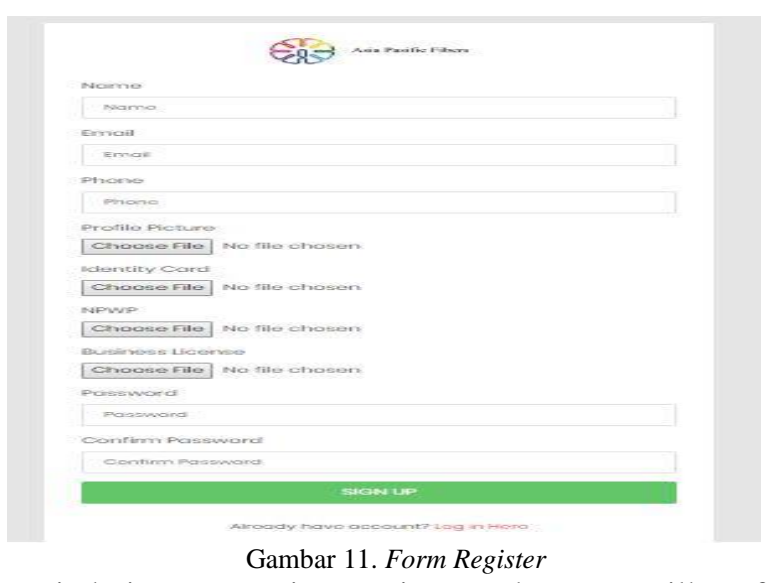

Fungsi dari menu register yaitu untuk menampilkan form pendaftaran peserta yang terdiri dari label nama, email, phone number, profile picture, Identity card, NPWP, Bussiness License

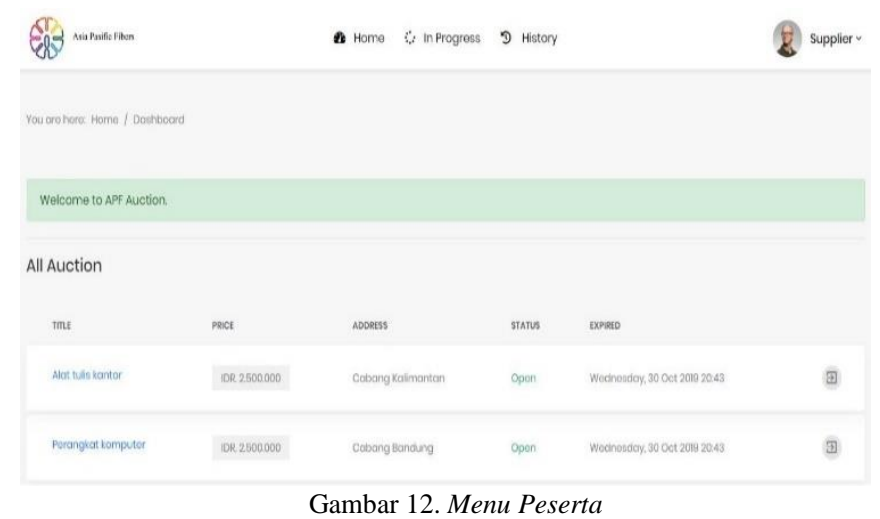

Halaman awal dari sistem lelang dan merupaka halaman awal apabia login sebagai peserta/ supplier.

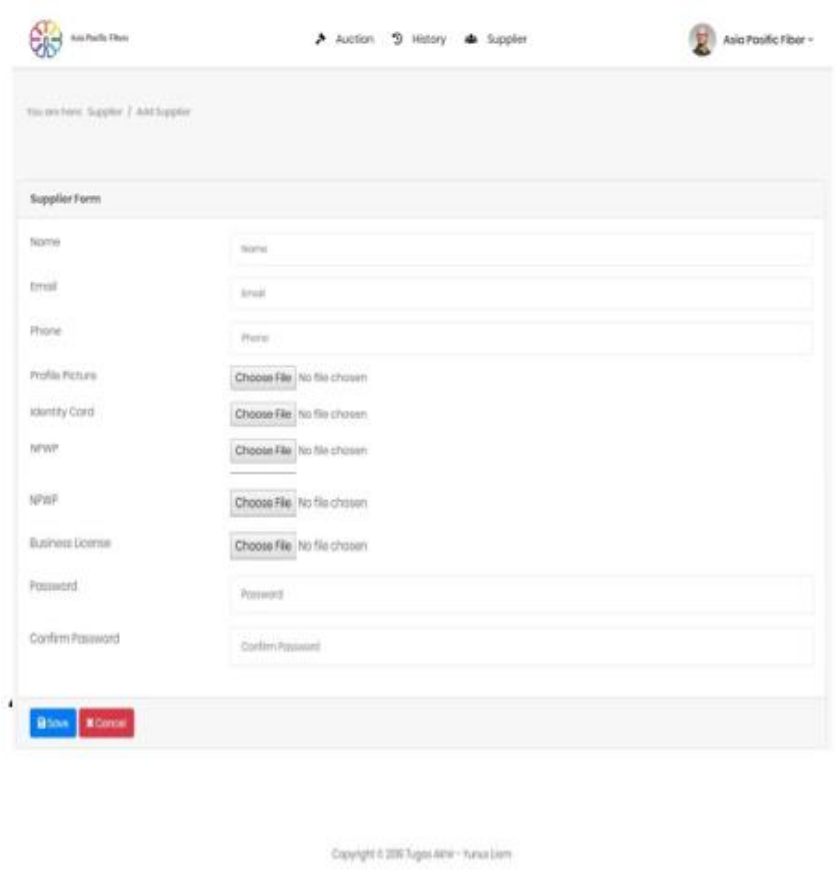

Gambar 12. Menu form Lelang

Peserta lelang wajib mengisi formulir dibawah guna untuk memberikan info dan sebagai persayaratan keikutsertaan lelang.

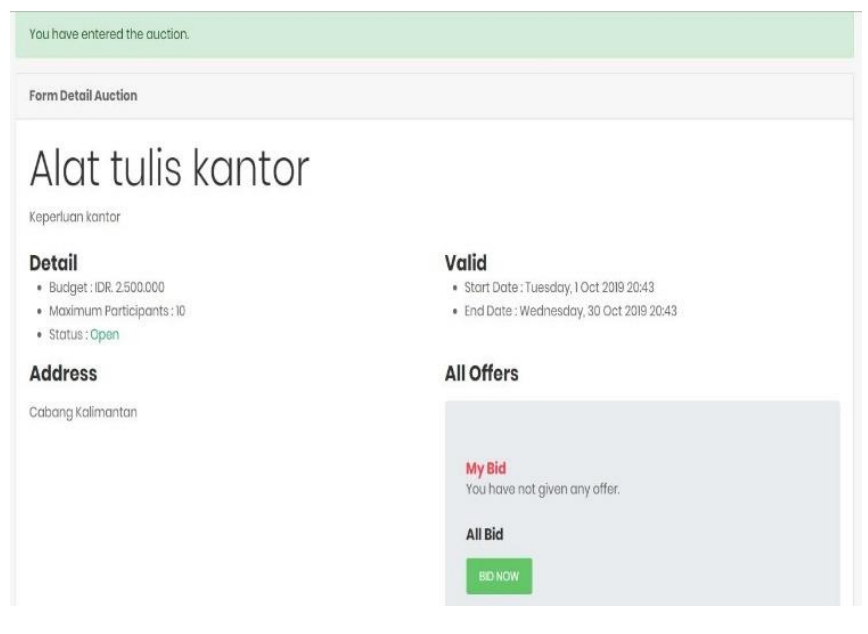

Gambar 13. Menu Lelang

Tampilan ini akan muncul bagi yang sudah melakukan pendaftaran dan muncul tombol bidnow. 


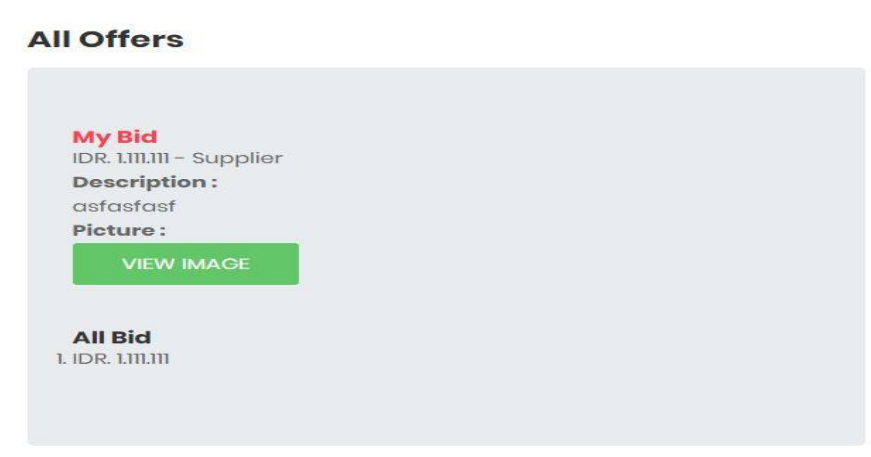

Gambar 14. Menu Hasil Penawaran peserta
Tampilan ini akan muncul ketika admin memeriksa penawaran yang dilakukan oleh peserta lelang.

\section{Pengujian Sistem}

Penulis menggunakan metode pengujian sistem yakni metode Blackbox Testing. Blackbox Testing adalah suatu metode pengujian perangkat lnak yang dilakukan dengan hanya mengamati hasil running melalui data uji dan memeriksa fungsional dari suatu perangkat lunak[14]. Jadi kita hanya bisa melihat tampilan luar (interface) perangkat lunak tersebut tanpa mengetahui apa yang terjadi dalam proses detail perangkat lunak tersebut (hanya input dan output).

TABEL X

BLACKBOX TESTING

\begin{tabular}{|c|c|c|c|c|}
\hline No. & $\begin{array}{l}\text { Fungsi yang } \\
\text { Diujikan }\end{array}$ & $\begin{array}{l}\text { Cara } \\
\text { Pengujian } \\
\end{array}$ & Hasil yang Diharapkan & Hasil Pengujian \\
\hline 1 & Menu Login & $\begin{array}{l}\text { Masukan } \\
\text { username dan } \\
\text { password }\end{array}$ & $\begin{array}{l}\text { Menampilkan form login dan berhasil masuk kedalam } \\
\text { menu home sebagai peserta/admin }\end{array}$ & $\begin{array}{l}\text { Sesuai dengan } \\
\text { harapan }\end{array}$ \\
\hline 2 & Menu Register & $\begin{array}{l}\text { Masukan } \\
\text { nama, } \\
\text { username dan } \\
\text { password }\end{array}$ & $\begin{array}{l}\text { Menampilkan form register dan berhasil mendaftarkan } \\
\text { akun peserta/supplier kedalam database }\end{array}$ & $\begin{array}{l}\text { Sesuai dengan } \\
\text { harapan }\end{array}$ \\
\hline 3 & Home Admin & $\begin{array}{l}\text { Login sebagai } \\
\text { Admin }\end{array}$ & $\begin{array}{l}\text { Menampilkan lelang yang telah dibuat dan tersedia } \\
\text { tombol untuk membuat new lelang, }\end{array}$ & $\begin{array}{l}\text { Sesuai dengan } \\
\text { harapan }\end{array}$ \\
\hline 4 & Home Supplier & $\begin{array}{l}\text { Login sebagai } \\
\text { Supplier }\end{array}$ & $\begin{array}{l}\text { Menampilkan status lelang dan bisa menuju ke menu } \\
\text { lelang Auction Join }\end{array}$ & $\begin{array}{l}\text { Sesuai dengan } \\
\text { harapan }\end{array}$ \\
\hline 5 & Home not Login & $\begin{array}{l}\text { Membuka } \\
\text { website }\end{array}$ & Menampilkan lelang yang sedang berjalan & $\begin{array}{l}\text { Sesuai dengan } \\
\text { harapan }\end{array}$ \\
\hline 6 & $\begin{array}{l}\text { Menu Lelang not } \\
\text { login }\end{array}$ & $\begin{array}{l}\text { Membuka } \\
\text { website }\end{array}$ & $\begin{array}{l}\text { Menampilkan detail lelang/ barang, tanpa harus } \\
\text { mengikuti lelang }\end{array}$ & $\begin{array}{l}\text { Sesuai dengan } \\
\text { harapan }\end{array}$ \\
\hline \multirow[t]{2}{*}{7} & $\begin{array}{l}\text { Menu peserta } \\
\text { Ikut Lelang }\end{array}$ & $\begin{array}{l}\text { Mengisi form } \\
\text { join auction }\end{array}$ & Menyimpan persayaratan peserta di database peserta & $\begin{array}{l}\text { Sesuai dengan } \\
\text { harapan }\end{array}$ \\
\hline & $\begin{array}{l}\text { Menu Buat } \\
\text { Lelang Admin }\end{array}$ & $\begin{array}{l}\text { Mengisi form } \\
\text { create } \\
\text { auction }\end{array}$ & Menyimpan data lelang di database & $\begin{array}{l}\text { Sesuai dengan } \\
\text { harapan }\end{array}$ \\
\hline 9 & $\begin{array}{l}\text { Menu Mengubah } \\
\text { Lelang }\end{array}$ & $\begin{array}{l}\text { Mengisi form } \\
\text { Edit Auction }\end{array}$ & $\begin{array}{l}\text { Menyimpan data lelang yang sudah di ubah dan } \\
\text { menampilkan hasil update di menu supplier dan not } \\
\text { login }\end{array}$ & $\begin{array}{l}\text { Sesuai dengan } \\
\text { harapan }\end{array}$ \\
\hline 10 & $\begin{array}{l}\text { Menu Mengubah } \\
\text { Peserta/Supplier }\end{array}$ & $\begin{array}{l}\text { Memilih edit } \\
\text { supplier }\end{array}$ & $\begin{array}{l}\text { Menyimpan data peserta yang sudah diubah dan } \\
\text { menampilkan hasil Update di menu Peserta }\end{array}$ & $\begin{array}{l}\text { Sesuai dengan } \\
\text { harapan }\end{array}$ \\
\hline 11 & $\begin{array}{l}\text { Menu Lelang Ikut } \\
\text { Peserta }\end{array}$ & $\begin{array}{l}\text { Berhasil } \\
\text { daftar, lalu } \\
\text { muncul } \\
\text { tombol Bid } \\
\text { now }\end{array}$ & Memunculkan menu penawaran peserta & $\begin{array}{l}\text { Sesuai dengan } \\
\text { harapan }\end{array}$ \\
\hline 12 & $\begin{array}{l}\text { Menu Penawaran } \\
\text { peserta }\end{array}$ & $\begin{array}{l}\text { Klik tombol } \\
\text { Bid now }\end{array}$ & Muncul halaman send yout offering & $\begin{array}{l}\text { Sesuai dengan } \\
\text { harapan }\end{array}$ \\
\hline 13 & $\begin{array}{l}\text { Hasil Penawaran } \\
\text { Peserta }\end{array}$ & $\begin{array}{l}\text { Mengisi form } \\
\text { penawaran } \\
\text { peserta }\end{array}$ & $\begin{array}{l}\text { Muncul halaman all offers /detail penawaran yang } \\
\text { sudah dimasukan }\end{array}$ & $\begin{array}{l}\text { Sesuai dengan } \\
\text { harapan }\end{array}$ \\
\hline 14 & $\begin{array}{l}\text { Menu Lelang } \\
\text { berakhir Peserta }\end{array}$ & $\begin{array}{l}\text { Menu lelang } \\
\text { Peserta, } \\
\text { mengklik } \\
\text { lelang yang }\end{array}$ & Muncul pemberitahuan lelang ini sudah berakhir & $\begin{array}{l}\text { Sesuai dengan } \\
\text { harapan }\end{array}$ \\
\hline
\end{tabular}




\begin{tabular}{|c|c|c|c|c|}
\hline & & $\begin{array}{l}\text { sudah status } \\
\text { close }\end{array}$ & & \\
\hline 15 & $\begin{array}{l}\text { Menu Lelang } \\
\text { Admin }\end{array}$ & $\begin{array}{l}\text { Memilih } \\
\text { lelang yang } \\
\text { sudah } \\
\text { berakhir }\end{array}$ & $\begin{array}{l}\text { Muncul halaman detail lelang yang sudah dibuat, lalu } \\
\text { ada tombol Choose The Winner }\end{array}$ & $\begin{array}{l}\text { Sesuai dengan } \\
\text { harapan }\end{array}$ \\
\hline 16 & $\begin{array}{l}\text { Halaman } \\
\text { Pemilihan } \\
\text { Pemenang }\end{array}$ & Klik Submit & Muncul rekomendasi pemenang untuk admin & $\begin{array}{l}\text { Sesuai dengan } \\
\text { harapan }\end{array}$ \\
\hline 17 & $\begin{array}{l}\text { Halaman } \\
\text { penawaran } \\
\text { peserta } a d m i n\end{array}$ & $\begin{array}{l}\text { Klik nama } \\
\text { peserta }\end{array}$ & Muncul halaman detail tentang pemenang & $\begin{array}{l}\text { Sesuai dengan } \\
\text { harapan }\end{array}$ \\
\hline 18 & $\begin{array}{l}\text { Halaman Lelang } \\
\text { berakhir Admin }\end{array}$ & $\begin{array}{l}\text { Klik End } \\
\text { Auction }\end{array}$ & Muncul pemberitahuan lelang berakhir & $\begin{array}{l}\text { Sesuai dengan } \\
\text { harapan }\end{array}$ \\
\hline 19 & $\begin{array}{l}\text { Menu History } \\
\text { lelang Admin }\end{array}$ & $\begin{array}{l}\text { Klik detail } \\
\text { (gambar } \\
\text { tanda seru !) }\end{array}$ & Muncul halaman detail lelang, serta pemenang & $\begin{array}{l}\text { Sesuai dengan } \\
\text { harapan }\end{array}$ \\
\hline
\end{tabular}

\section{KESIMPULAN}

Berdasarkan uraian-uraian yang telah penulis paparkan, maka penulis dapat mengambil kesimpulan bahwa perlu adanya sistem baru yang dibuat di harapkan dapat membantu dalam hal mengambil keputusan untuk memecahkan permaslaahan di PT Asia Pacific Fibers. Perancangan sistem meliputi penyimpanan data yang sudah tersimpan kedalam database dapat membantu mengurangi kemungkinan berkas data yang basah, kotor, maupun hilang sehingga efisien dalam hal waktu dalam melakukan pencarian dan penyimpanan data. Adanya sistem informasi lelang berbasis web, supplier, bagian admin serta kepala gudang yang menangani berbagai kegiatan dapat menjadi sangat terbantu karena kegiatannya sudah terkomputerisasi. Pengelolahan data supplier, mencari barang dengan harga terendah, mencari supplier, pengelolahan barang dan lain-lain menjadi lebih cepat karena adanya sistem informasi lelang berbasis web ini pada PT Asia Pacific Fibers.

\section{DAFTAR PUSTAKa}

[1] A. M. Sari, "Aplikasi Situs Web Penjualan Hijab Online," Paradigma, 2017.

[2] R. K. Tanesia, "Studi Efektivitas Pengadaan Barang Dan Jasa Pemerintah Secara Tradisional dan Elektronik," J. Tek. Sipil, 2016.

[3] Z. Azhar, "Penerapan Metode Analytical Hierarchy Process Dalam Pemilihan Bibit Jagung Unggul," JURTEKSI (Jurnal Teknol. dan Sist. Informasi), 2020.

[4] Fendi Nurcahyono, "Pembangunan Aplikasi Penjualan Dan Stok Barang Pada Toko Nuansa Elektronik Pacitan," Sentra Penelit. Eng. dan Edukasi, 2012.

[5] M. I. Akbar, "Analisis Dan Perancangan Sistem Informasi Persediaan Produk Berbasis Web Pada PT AI," SISTEMASI, 2019.

[6] S. Kosasi and J. S. Informasi, "Perancangan Sistem Lelang Online dalam Pengadaan Barang dan Jasa," $J$. Sist. Inf., 2015.

[7] T. Saaty and L. Vargas, Models, methods, concepts \& applications of the analytic hierarchy process. 2012.

[8] Abdul Kadir, "Pengenalan Sistem Informasi Edisi Revisi," Edisi Revisi. 2014.

[9] D. Purnomo, "Model Prototyping Pada Pengembangan Sistem Informasi," J I M P - J. Inform. Merdeka Pasuruan, 2017.

[10] H. Jogiyanto, "Sistem Teknologi Informasi," Ranc. Bangun Sist. Inf. Penjualan Pada Mina Mark. Benowo, 2005.

[11] T. Makmur, "Teknologi Informasi," Info Bibl. J. Perpust. dan Ilmu Inf., 2019.

[12] A. Setiawan, R. Soelaiman, and R. J. Akbar, "Rancang Bangun Aplikasi Pelelangan Online (E-Auction) berbasis Perangkat Bergerak Android," J. Tek. ITS, 2017.

[13] "Prototype Model," in Encyclopedia of Production and Manufacturing Management, 2006.

[14] Fernanda Yuwanda, "Black Box Testing | Pengujian Perangkat Lunak," 14 April, 2016. .

[15] I. Bastian, R. D. Winardi, and D. Fatmawati, "Metoda Wawancara," Metod. Pengumpulan dan Tek. Anal. Data, 2018.

[16] H. Hasanah, "Teknik-Teknik Observasi,” At-Taqaddum, 2017.

[17] E. Darmanto et al., "Penerapan Metode Ahp ( Analythic Hierarchy Process ) Untuk," J. SIMETRIS, 2014.

[18] 2013 Rosa \& Salahuddin, "UML, Use Case Diagram, Activity Diagram, Class Diagram," in Rekayasa Perangkat Lunak Terstruktur, 2013.

[19] R. Dachroni, R. Erafidah, E. Mandala, and S. Sepriandi, "Implementasi Sistem Lelang Elektronik (EProcurement) Oleh Pemerintah Kota Tanjungpinang," JDP (JURNAL Din. PEMERINTAHAN), 2019.

[20] M. Putriningsih, S.P, Riyanto, B. R, "Prosedur Penjualan Lelang Atas Aset Kendaraan Milik Universitas Diponegoro," Diponegoro Law J., 2016. 